\title{
ANTECEDENTS OF ENTREPRENEURIAL AND INTRAPRENEURIAL INTENTIONS: EVIDENCE FROM BRAZIL
}

Antecedentes das intenções empreendedoras e intraempreendedoras: evidências do Brasil

Danilo Magno Marchiori

E-mail: danilo.marchiori@gmail.com Mestre em Administração de Empresas pela Fundação Instituto Capixaba de Pesquisas em Contabilidade, Economia e Finanças; Doutorando em Gestão na Universidade da Beira Interior, Portugal; Professor no Programa de Pós-graduação Profissional em Gestão Pública da Universidade Federal do Espírito Santo. Endereço para contato: Avenida Fernando Ferrari, 514, Goiabeiras, 29075-910, Vitória, Espírito Santo, Brasil. https://orcid.org/0000-0002-7386-9706

Maria José Aguilar Madeira

E-mail: maria.jose.madeira@ubi.pt Phd em Gestão pela Universidade da Beira Interior, Portugal; Mestre em Gestão pela Universidade da Beira Interior, Portugal; Professora Auxiliar com Agregação da Universidade da Beira Interior, Portugal; Investigadora do NECE - Research Center in Business Sciences. https://orcid.org/0000-0003-1722-6148

Anabela do Rosario Leitão Dinis

E-mail: adinis@ubi.pt Phd em Gestão pela Universidade da Beira Interior, Portugal; Doctoral Course (Ciencias Economicas e Empresariales) pela Universitat Autònoma de Barcelona, Espanha; Professora Auxiliar na Universidade da Beira Interior, Portugal; Investigadora do NECE - Research Center in Business 


\section{Abstract}

The general objective of the present study is to identify the antecedents of the entrepreneurial and intrapreneurial intentions of 266 potential entrepreneurs, represented by students of the degree courses in Business Administration and Accounting Sciences in brazilians higher education institutions. For this purpose, as specific objectives we sought to identify whether entrepreneurial and intrapreneurial behavior are seen as different career options by students, as well as understanding the degree of relative importance for students of the attributes of property, income expectation, extra work tolerance, desire for autonomy and risk of income variation. For the data analysis, we specified structural equation models, with a confirmatory factorial analysis, as well as using the conjoint analysis approach of the attributes selected for the study. The results indicate that the constructive entrepreneurial intentions and intrapreneurial intentions are perceived as different career options by the students. The results also indicate that the most valued attribute by the respondents to define professional choice is income expectation and the least valued is the tolerance to the accomplishment of additional effort. Finally, the results point out that the income expectation variable is antecedent of the entrepreneurial intentions, and no other significant relationships were detected.

Keywords: Entrepreneurial intentions. Intrapreneurial intentions. Intrapreneurship. Structural equation models. Conjoint analysis.

\section{Resumo}

Oobjetivo geral com o presente estudo foiidentificarosantecedentes das intenções empreendedoras e intraempreendedoras de 266 potenciais empreendedores, representados por estudantes dos cursos superiores de administração e ciências contábeis de instituições de ensino superior brasileiras. Para tanto, como objetivos específicos, buscou-se identificar se o comportamento empreendedor e o intraempreendedor são vistos como diferentes opções de carreira por estudantes, bem como compreender o grau de importância relativa para os estudantes dos atributos propriedade, expectativa de renda, tolerância ao trabalho extra, desejo de autonomia e risco de variação de renda. Para a análise dos dados foram especificados modelos de equações estruturais, com a realização de análise fatorial confirmatória, bem como utilizada a técnica da análise conjunta dos atributos selecionados para o estudo. Os resultados indicam que os construtos intenções empreendedoras e intenções intraempreendedoras são percebidos como diferentes opções de carreira pelos estudantes. Os resultados indicam, ainda, que o atributo mais valorizado pelos respondentes para a definição da escolha profissional foi a expectativa de renda, e o menos valorizado foi a tolerância à realização de esforço adicional. Por fim, os resultados apontaram que a variável expectativa de renda também é antecedente das intenções empreendedoras, não tendo sido detectadas outras relações significativas.

Palavras-chave: Intenções empreendedoras. Intenções intraempreendedoras. Intraempreendedorismo. Modelos de equações estruturais. Análise conjunta.

\section{INTRODUCTION}

Individuals may exhibit entrepreneurial behavior within established organizations (Douglas \& Fitzsimmons, 2013). This type of entrepreneurial intention is related to a phenomenon known in the literature as intrapreneurship (Pinchot, 1985). Various studies have emphasized the importance of 
intrapreneurship (at a personal level) for the development of corporate entrepreneurship (at an organizational level), which is fundamental to economic growth and the development of global competitiveness (Lumpkin \& Dess, 1996; Morris \& Kurratko, 2002; Davidsson, 2006; Bolton \& Lane, 2012; Bolton, 2012; Douglas \& Fitzsimmons, 2013).

However, Douglas and Fitzsimmons (2013) identified that the literature on entrepreneurial intentions has almost exclusively addressed individuals' intentions to become owners and managers of new businesses (Bird, 1988, 1992; Krueger, 1993; Krueger \& Carsrud, 1993; Krueger \& Brazeal, 1994; Gupta, Turban, Wasti, \& Sikdar, 2009; Liñán \& Chen, 2009; Thompson, 2009; Fitzsimmons \& Douglas, $2011)$. According to the authors, there is little empirical evidence to date about the antecedents of intrapreneurial intentions. Therefore, to explore this gap, Douglas and Fitzsimmons (2013) conducted a study of students from four different Asian countries and identified that entrepreneurship and intrapreneurship are considered different manifestations of entrepreneurial intentions (or career options). In addition, the results indicate that individual preferences related to income, ownership, and autonomy explain entrepreneurial attitudes, while risk aversion is related to intrapreneurial attitudes.

Despite this contribution from Douglas and Fitzsimmons (2013), the antecedents of intrapreneurial intentions continue to lack empirical studies in the literature. One notable fact is that most of the hypotheses proposed and tested by Douglas and Fitzsimmons (2013) were not supported by the data. In addition, the authors suggested that their research be replicated in other cultural and geographic contexts. Thus, the present study explored this opportunity by replicating Douglas and Fitzsimmons (2013) research among Business Administration and Accounting Sciences students in Brazil. In this sense, the primary objective of this study was to identify if five variables - property, income expectation, tolerance for extra work, desire for autonomy, and risk of income variation are antecedents of entrepreneurial and intrapreneurial intentions. To do so, two preliminary steps were taken: identifying whether entrepreneurial and intrapreneurial behavior are considered different career options, and measuring the relative importance of the attributes property, income expectation, tolerance for extra work, desire for autonomy, and risk of income variation to students. Complementarily and exploratorily, this study also tested for significant differences in gender and major in relation to entrepreneurial and intrapreneurial intentions.

From a practical perspective, identifying different antecedents of intrapreneurial and entrepreneurial intentions can influence the politics of employee selection in organizations, as well as provide subsidies for teaching strategies and entrepreneurial development. Theoretically, replicating the Douglas and Fitzsimmons (2013) study in a different context may contribute to the provision of subsidies for comparison of the results. In addition, the verification of a distinction between intrapreneurship and entrepreneurship was conducted using a confirmatory factor analysis based on the results of the exploratory factor analysis conducted by Douglas and Fitzsimmons (2013). Thus, the present study goes a step further by robustly validating the methods of measuring entrepreneurial and intrapreneurial intentions presented by the authors. 


\section{LITERATURE REVIEW}

\subsection{ENTREPRENEURSHIP AND INTRAPRENEURSHIP: DIFFERENT OPTIONS OF ENTREPRENEURIAL BEHAVIOR}

The literature includes some studies of entrepreneurial and intrapreneurial behavior. More specifically, Burgelman (1983) examined the process of exploring business opportunities within established enterprises, that is, the process conducted by intrapreneurs. The case study conducted by the author identified three factors that favor exploring new business opportunities in established companies: the possibility of engaging employees in autonomous business activities; the ability of mid-level managers to identify the strategic implications of such initiatives; and senior management authorization to modify the corporate competitive strategy based on viable initiatives.

Eighteen years later, Honig (2001) empirically studied the different learning strategies of entrepreneurs and intrapreneurs. Their results indicate that intrapreneurs rely more strongly on organizational consensus, while entrepreneurs focus more on flexible and adaptive strategies less suitable for static environments. Parker (2011), in turn, studied the factors that drive entrepreneurial and intrapreneurial behavior. The author identified that new businesses created by entrepreneurs generally focus on marketing products and services directly to clients, while intrapreneurs explore business opportunities with other organizations.

Finally, Douglas and Fitzsimmons (2013) focused specifically on the differences in cognitive antecedents of entrepreneurial and intrapreneurialintentions. Morespecifically, the authors conducted a study of 414 MBA students from Australia, China, India, and Thailand and used an exploratory factor analysis (EFA) to analyze the responses. As a result, they identified that entrepreneurship and intrapreneurship were considered by the participants to be different entrepreneurial behaviors (or career options). Therefore, the logical next step in the investigation would be a confirmatory factor analysis (CFA) based on the results found by Douglas and Fitzsimmons (2013). This opportunity is explored in the present study.

\subsection{INTRAPRENEURIAL AND ENTREPRENEURIAL INTENTIONS: COGNITIVE ANTECEDENTS}

As highlighted by Douglas and Fitzsimmons (2013), the literature on entrepreneurial intentions has almost exclusively addressed individuals' intentions to become owners of new businesses (Bird, 1988, 1992; Krueger, 1993; Krueger \& Carsrud, 1993; Krueger \& Brazeal, 1994; Gupta et al., 2009; Liñán \& Chen, 2009; Thompson, 2009; Fitzsimmons \& Douglas, 2011), and few studies have empirically focused on the cognitive antecedents of individuals' intentions to become intrapreneurs.

Two exceptions are the studies by Monsen, Patzelt, and Saxton (2010) and Douglas and Fitzsimmons (2013). In the first study, the authors developed a theoretical model integrating the financial, risk, and effort factors to explain employee engagement in new corporate projects (intrapreneurial behavior). The results indicated that employees' intrapreneurial intentions are negatively related to their perception of risk exposure and the level of extra work required. On the 
other hand, Monsen et al. (2010) found a positive relationship between intrapreneurial intentions and expectations of profit distribution (or bonuses) generated by corporate projects.

Bolton and Lane (2012) presented and tested a measure of individual entrepreneurial orientation using a sample of students who served as a proxy for future entrepreneurs. Later, Bolton (2012) advanced the study and reinforced the validity of the new measure for entrepreneurs, identifying that risk exposure, proactivity, and innovative behavior are factors of individual entrepreneurial orientation. In the context that entrepreneurship is a consequence of the development of institutions that encourage entrepreneurial behavior, Urban (2013) identified that the institutional, regulatory, and normative dimensions of organizations affect innovative behavior within existing organizations. In turn, Ferreira, Raposo, Rodrigues, Dinis, and Do Paço (2012) identified that need for achievement, self-confidence, and personal attitude positively affect entrepreneurial intention, and subjective norms and personal attitude affect perceived behavioural control.

Douglas and Fitzsimmons (2013) studied the formation of individuals' intentions to act entrepreneurially, both individually (entrepreneurship) and within an organization (intrapreneurship). To do so, the authors studied five factors that could explain individuals' intentions: income expectation, decision-making autonomy, company ownership, risk tolerance, and tolerance for extra work. The results found by Douglas and Fitzsimmons (2013) suggest that the interviewees' attitudes towards income, property, and autonomy are antecedents of entrepreneurship alone. On the other hand, risk aversion seems to be exclusively related to intrapreneurship.

\section{METHODOLOGY}

The present study is based on a quantitative and descriptive strategy in which a cross-sectional study was conducted to obtain primary data through a questionnaire. The population comprises undergraduate students of Business Administration and Accounting Sciences majors in three Higher Education Institutions (HEI), located in the states of Minas Gerais (one) and Espírito Santo (two), Brazil. The choice of majors is justified by the fact that future professionals are trained in the management and control of new or existing organizations. Thus, the students served as proxies for future entrepreneurs.

The questionnaires were distributed in classrooms in printed form, with the support of each HEl's administration, in October 2015. After completion, 279 questionnaires were collected and their responses were typed into a spreadsheet. However, after careful evaluation of the answers, it was found that 13 questionnaires presented completion problems (e.g. incomplete answers, more than one response to the same question, or the same response to every question). These questionnaires were removed, bringing the final total of completed questionnaires used for data analysis to 266.

In the first part of the questionnaire, in order to verify if entrepreneurial and intrapreneurial behavior are perceived as different constructs, seven statements were developed and presented to the respondents, according to Douglas and Fitzsimmons (2013). Respondents were asked to indicate their likelihood of carrying out each proposed action in the future. A seven-point Likert scale was used, ranging from "very unlikely" to "very likely". The second part was designed with the objective of 
allowing a conjoint analysis to be conducted. It comprised 32 questions, each offering the respondent choices related to income expectation, decision-making autonomy, company ownership, income variation risk tolerance, and tolerance for extra work. Each respondent had to indicate how much they agreed with each choice on a seven-point Likert scale ranging from "strongly disagree" to "strongly agree". To avoid problems with the order of the answers, four types of questionnaire were generated and distributed, each with a different order for the choices. Finally, the third part of the questionnaire was designed to collect demographics to characterize the sample: gender, age, state, major, and school status (student or student worker).

Several techniques were used for the data analysis. First, in order to confirm the theory for measuring entrepreneurial and intrapreneurial intentions presented by Douglas and Fitzsimmons (2013), a confirmatory factor analysis (CFA) was applied by constructing a structural equation model (SEM). The measurement models for the two constructs were calculated using an incremental index (CFI) and an absolute index (GFI) of model adjustment (Hair, Black, Babin, Anderson, \& Tatham, 2009). The normality of the data was also verified by analyzing symmetry and kurtosis, as well as calculating the necessary indicators to verify convergent and discriminant validity and composite reliability. The calculations and parameters adopted are in line with Hair et al. (2009).

In order to determine the degree of relative importance of each attribute (property, income, work, autonomy, and risk), a joint analysis was conducted. According to Hair et al. (2010), this technique is used to understand how respondents develop preferences. Thus, the degree of importance that each respondent attributes to each factor, as well as quality indicators for the model (Pearson's $r$ and Kendall's tau), were calculated. After calculating the attributes' utilities, the relationship between the attributes and entrepreneurial and intrapreneurial intentions was verified. Therefore, two structural equation models were constructed based on the CFA conducted in the present study.

One point worth mentioning is that the SEM technique applied in the present study represents a step forward in relation to the strategy used by Douglas and Fitzsimmons (2013) with the same objective (regression). This decision is justified because the first part of the study used structural equation models to conduct the CFA and maintaining the technique was the most coherent decision. Moreover, the use of structural equation models adds robustness to the study because it uses reflective constructs, rather than averages, to form dependent variables, as in Douglas and Fitzsimmons (2013).

\section{ANALYSIS AND DISCUSSION}

In order to characterize the sample, the questionnaire collected demographics about the respondents, summarized in Table 1: 
Table 1

Sample characterization

\begin{tabular}{|c|c|c|c|}
\hline Characteristics & Options & Frequencies & $\%$ \\
\hline \multirow{2}{*}{ Gender } & Female & 167 & $62.8 \%$ \\
\hline & Male & 99 & $37.2 \%$ \\
\hline \multirow{2}{*}{ Major } & Business Administration & 226 & $85.0 \%$ \\
\hline & Accounting Sciences & 40 & $15.0 \%$ \\
\hline \multirow{2}{*}{ State } & Espírito Santo & 198 & $74.4 \%$ \\
\hline & Minas Gerais & 68 & $25.6 \%$ \\
\hline \multirow{2}{*}{ School status } & Student & 77 & $28.9 \%$ \\
\hline & Student worker & 189 & $71.1 \%$ \\
\hline \multirow{4}{*}{ Age } & 20 years or less & 65 & $24.4 \%$ \\
\hline & 21 to 25 years & 112 & $42.10 \%$ \\
\hline & 26 to 30 years & 47 & $17.7 \%$ \\
\hline & 31 years and over & 42 & $15.8 \%$ \\
\hline
\end{tabular}

The most common profile among the respondents was the female Business Administration student living in the state of Espírito Santo, aged between 20 and 25 and working while studying. This profile conforms to the demographics of the researched population, according to data from the HEl administrations that participated in this study. Thus, the sample was considered to satisfactorily represent the population, satisfying the objectives of this study.

The first technique used to analyze the data was a CFA conducted on the measure proposed by Douglas and Fitzsimmons (2013). The first step was to verify the assumed normality of the distribution by evaluating the kurtosis and asymmetry of the observations. Considering that no distribution problems were found, the structural equation models underwent specification exactly as proposed by the authors. The analysis of the initial model showed that all seven items were significant at the $5 \%$ level. However, the adjustment quality indicators showed values below the appropriate CFI = 0.818 and $\mathrm{GFI}=0.868$. In addition, a more careful observation revealed a low load factor in the variable EMP3 $\left(r=0.49\right.$ and $\left.r^{2}=0.24\right)$, meaning that more than $50 \%$ of the variation of this variable was not explained by the latent factor of entrepreneurial intentions. Therefore, considering that the constructs in question can be considered reflective, that is, each observed variable is explained by the latent construct and its withdrawal does not interfere with its explanatory power (Hair et al., 2009), EMP3 was removed and the model was recalculated. Consequently, the new model showed higher adjustment indicators $(\mathrm{CFI}=0.928$ and $\mathrm{GFI}=0.950)$, as can be observed in Figure 1. These results suggest that the adjusted model is better suited for measuring entrepreneurial intentions than the model proposed by Douglas and Fitzsimmons (2013). 

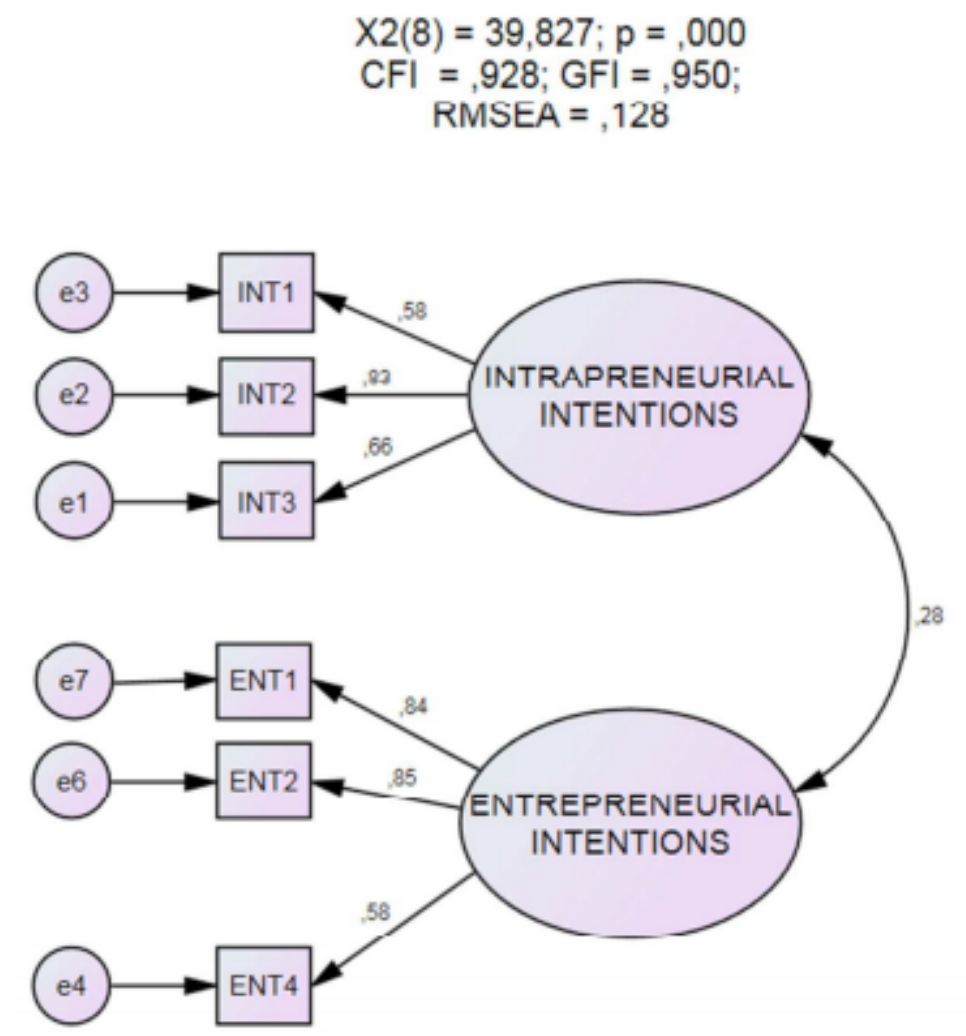

Figure 1. Adjusted measurement model. Adapted from "Intrapreneurial intentions versus entrepreneurial intentions: Distinct constructs with different antecedents," by E. J. Douglas and J. R. Fitzsimmons, 2013, Small Business Economics, 41 (1), p. 115-132.

The next step of the CFA was to calculate the construct reliability (CR), the convergent validity (high proportion of common variance of the items of a construct), and the discriminant validity (degree to which one construct differs from the others), as explained by Hair et al. (2009). The calculations and parameters used are presented in Table 2:

Table 2

Construct reliability and validities

\begin{tabular}{|c|c|c|c|}
\hline \multirow{3}{*}{ Construct } & Reliability & $\begin{array}{l}\text { Convergent } \\
\text { Validity }\end{array}$ & Discriminant Validity \\
\hline & \multirow{2}{*}{$(C R \geq 0.7)$} & \multirow{2}{*}{$(A \vee E \geq 0.5)$} & $\left(A \bigvee E>r^{2}\right)$ \\
\hline & & & INTRAPRENEURIAL INTENTIONS \\
\hline INTRAPRENEURIAL INTENTIONS & 0.73 & 0.48 & \\
\hline ENTREPRENEURIAL INTENTIONS & 0.81 & 0.59 & 0.08 \\
\hline
\end{tabular}

An analysis of the results revealed that the constructs entrepreneurial intentions and intrapreneurial intentions, resulting from the adjustment performed in the first step, have adequate levels of reliability, higher than the value of 0.7 indicated by Hair et al. (2009). Likewise, the constructs adequately differ among themselves, insofar as the values of the constructs' mean variances are greater than the square of the correlation estimate between them, that is, they indicate discriminant validity. However, it was found that, at the limit, there was a problem involving the discriminant validity 
of the construct intrapreneurial intentions: the value of the average variance extracted (0.48) was lower than the appropriate limit of 0.5 (Hair et al., 2009). Based on this result and the low load factor of EMP3, a revision of the original theory to measure intrapreneurial intentions is recommended, as well as other investigations that test this specific question of the model proposed by Douglas and Fitzsimmons (2013).

Following the CFA, the data were calculated for a joint analysis. First, the model's quality indicators were calculated in order to assure accuracy of the interpretation of the results. The values of Pearson's r (0.982) and Kendall's tau (0.930) were satisfactory. The results can be observed in Table 3:

Table 3

Utilities and relative importance

\begin{tabular}{|c|c|c|c|}
\hline Attributes & Levels & Utilities & Relative Importance \\
\hline \multirow{2}{*}{ Property } & owner & 0.111 & \multirow{2}{*}{$19.7 \%$} \\
\hline & employee & -0.111 & \\
\hline \multirow{2}{*}{ Income expectation } & high & 0.449 & \multirow{2}{*}{$29.1 \%$} \\
\hline & low & -0.449 & \\
\hline \multirow{2}{*}{ Tolerance for extra work } & high & -0.077 & \multirow{2}{*}{$15.2 \%$} \\
\hline & low & 0.077 & \\
\hline \multirow{2}{*}{ Autonomy and responsibility expectation } & high & 0.145 & \multirow{2}{*}{$16.3 \%$} \\
\hline & low & -0.145 & \\
\hline \multirow{2}{*}{ Risk of income variation } & high & -0.168 & \multirow{2}{*}{$19.7 \%$} \\
\hline & low & 0.168 & \\
\hline Constant & & & 3.999 \\
\hline Pearson's $r$ & & & 0.982 \\
\hline Kendall's tau & & & 0.930 \\
\hline
\end{tabular}

Considering the total number of respondents, the data suggest that the most valued factor was expectation of future income (29.1\%). Next, the importance of organization property and income variation appear to be tied (19.7\%). The fourth most important factor was expectation of decision-making autonomy and responsibility assumption (16.3\%). Finally, the least important factor to interviewees was tolerance for extra work (15.2\%). That is, respondents placed about twice as much value in income expectation as in exerting greater effort in their work. This data gains importance in light of the fact that most of the interviewees already have experience in the labor market. Thus, the results suggest that respondents prefer to receive a higher work load in exchange for higher income.

In order to test if the variables property, income, work tolerance, autonomy, and risk tolerance are antecedents of entrepreneurial and intrapreneurial intentions for the researched population, two structural equation models were specified and estimates for the degrees of significance of each relationship were calculated. The results are presented in Table 4 and the complete models are included in Appendix 1 of this study. 
Table 4

Estimates of regression weights

\begin{tabular}{llllrrrr}
\hline & & & & Estimate & \multicolumn{1}{l}{ S.E. } & C.R. & P \\
\hline \multirow{4}{*}{$\begin{array}{llllrl}\text { Entrepreneurial } \\
\text { intentions }\end{array}$} & Property & $<--$ & ENTRE & -0.466 & 0.772 & -0.604 & 0.546 \\
& Income & $<---$ & ENTRE & 2.17 & 0.979 & 2.216 & 0.027 \\
& Work & $<---$ & ENTRE & -0.352 & 0.616 & -0.571 & 0.568 \\
& Autonomy & $<---$ & ENTRE & -0.079 & 0.622 & -0.128 & 0.899 \\
& Risk & $<--$ & ENTRE & -1.273 & 0.78 & -1.632 & 0.103 \\
\hline \multirow{4}{*}{ Intrapreneurial } & Property & $<---$ & INTRA & 0.786 & 1.141 & 0.689 & 0.491 \\
& Income & $<---$ & INTRA & 1.842 & 1.45 & 1.271 & 0.204 \\
& Work & $<---$ & INTRA & -1.113 & 0.911 & -1.221 & 0.222 \\
& Autonomy & $<---$ & INTRA & 0.029 & 0.92 & 0.032 & 0.975 \\
& Risk & $<---$ & INTRA & -1.545 & 1.155 & -1.338 & 0.181 \\
\hline
\end{tabular}

An analysis of Table 4 indicates that of the ten relationships tested, only income showed statistical significance in explaining entrepreneurial intentions. In other words, the results suggest that the greater respondents' expectation to receive a higher income in the future, the greater their willingness (or intention) to create their own business, either to introduce a radical innovation to the market or to explore a variation of an existing product or service. This result is in line with the studies of Douglas and Fitzsimmons (2013) and Douglas and Shepherd (2002) on this specific aspect.

On the other hand, the other variables studied did not present statistical significance in explaining entrepreneurial and intrapreneurial intentions. One possible explanation is the fact that the population of the present study comprised undergraduate students of all grades. Still, previous research that found other significant relationships (Douglas \& Fitzsimmons, 2013) identified a relationship between income variation risk and intrapreneurial intentions) assessed the entrepreneurial intentions of students at a higher academic level (MBA students). This may indicate that entrepreneurial and intrapreneurial intentions may form or change over time based on accumulation of professional and academic experiences. Future longitudinal research could test this proposition.

Finally, complementarily and exploratorily, it was verified whether the variables gender and major produce statistically significant differences in entrepreneurial and intrapreneurial intentions. Two multiple imputation and multiple causes models (MIMIC) were defined using structural equation models, as proposed by Jöreskog and Goldberger (1975). The regression weight estimates are presented in Table 5:

Table 5

Estimates for gender and major variables

\begin{tabular}{|c|c|c|c|c|c|c|c|c|}
\hline \multirow{3}{*}{$\begin{array}{l}\text { Construct } \\
\text { Entrepreneurial } \\
\text { Intentions }\end{array}$} & \multirow{2}{*}{$\begin{array}{c}\text { Variable } \\
\text { Gender* }\end{array}$} & \multicolumn{3}{|c|}{ Relationships } & \multirow{2}{*}{$\begin{array}{r}\text { Estimate } \\
0.295\end{array}$} & \multirow{2}{*}{$\frac{\text { S.E. }}{0.18}$} & \multirow{2}{*}{$\frac{\text { C.R. }}{1.61}$} & \multirow{2}{*}{$\frac{P}{0.11}$} \\
\hline & & ENTRE_INT & $<--$ & Gender & & & & \\
\hline & Major** & ENTRE_INT & $<--$ & Major & 0.628 & 0.25 & 2.51 & 0.01 \\
\hline \multirow{2}{*}{$\begin{array}{l}\text { Intrapreneurial } \\
\text { Intentions }\end{array}$} & Gender* & INTRA_INT & $<--$ & Gender & 0.105 & 0.13 & 0.81 & 0.42 \\
\hline & Major** & INTRA_INT & $<--$ & Major & 0.284 & 0.18 & 1.61 & 0.11 \\
\hline
\end{tabular}

Note. *Gender: Men=0 and Women=1; **Major: Administration=0 and Accounting Sciences=1. 
The results in Table 5 indicate that only one relationship is statistically significant: Accounting Sciences students presented higher indicators of entrepreneurial intentions when compared to Business Administration students. This result is somewhat contrary to the initial expectations of this study, since it was expected that training students in organization management would be conducive to higher levels of entrepreneurial intentions. No other significant relationships were found. That is, there was no relation between gender and students' entrepreneurial and intrapreneurial intentions, and major had no relation to intrapreneurial intentions.

\section{CONCLUSIONS}

The present study focused on the antecedents of entrepreneurial and intrapreneurial intentions of Business Administration and Accounting Sciences undergraduate students in Brazil. More specifically, this study sought to identify if property, income expectation, tolerance for extra work, desire for autonomy, and income variation risk tolerance are antecedents of entrepreneurial and intrapreneurial intentions. The results showed that only income expectation is significant in explaining entrepreneurial intentions. No other significant relationships were detected.

To achieve the main objective of this study, the first step was to identify if entrepreneurial and intrapreneurial behavior are viewed as different career options. The results of the CFA suggest that they are. The study also identified that the most important attribute to respondents when making this professional decision was income expectation, while the least important was tolerance for extra work.

Complementarily, this study tested for significant differences in gender and major in relation to entrepreneurial and intrapreneurial intentions. The results showed that, contrary to expectations, Accounting Sciences students showed higher levels of entrepreneurial intentions compared to Business Administration students.

In theory, this study contributes to the validation of the measure of entrepreneurial and intrapreneurial intentions, pointing out its deficiencies in Douglas and Fitzsimmons (2013). The study also contributes to the literature in that it uses more robust and complementary statistical techniques in relation to previous studies. In addition, the results of the present study can be compared with other studies that address the same theme, since there is little empirical evidence of the antecedents of entrepreneurial intentions and, above all, intrapreneurial intentions.

However, this study presents a limitation in using a non-probabilistic sampling technique for convenience. Thus, caution is recommended regarding generalization of the results. It is also recommended that future researchers longitudinally investigate the entrepreneurial and intrapreneurial intentions that form or change over time based on accumulation of professional and academic experiences. Finally, according to studies by Bolton (2012) and Bolton and Lane (2012), it is suggested that the present study be conducted with a sample of professionals already active in the market (nonstudents). 


\section{REFERENCES}

Bird, B. J. (1988). Implementing entrepreneurial ideas: The case for intention. Academy of management Review, 13(3), 442-453.

Bird, B. J. (1992). The operation of intentions in time: The emergence of the new venture. Entrepreneurship: Theory and Practice, 17(1), 11-21.

Bolton, D. L., \& Lane, M. D. (2012). Individual entrepreneurial orientation: Development of a measurement instrument. Education+Training, 54 (2-3), 219-233.

Bolton, D. L. (2012). Individual entrepreneurial orientation: Further investigation of a measurement instrument. Academy of Entrepreneurship Journal, 18(1), 91.

Burgelman, R. A. (1983). A process model of internal corporate venturing in the diversified major firm. Administrative science quarterly, 223-244.

Davidsson, P. (2006). Method challenges and opportunities in the psychological study of entrepreneurship. The psychology of entrepreneurship, 287-323.

Douglas, E. J., \& Fitzsimmons, J. R. (2013). Intrapreneurial intentions versus entrepreneurial intentions: Distinct constructs with different antecedents. Small Business Economics, 41 (1), 115-132.

Douglas, E. J., \& Shepherd, D. A. (2002). Self-employment as a career choice: Attitudes, entrepreneurial intentions, and utility maximization. Entrepreneurship theory and practice, 26(3), 81-90.

Ferreira, J. J., Raposo, M. L., Rodrigues, R. G., Dinis, A., \& Do Paço, A. (2012). A model of entrepreneurial intention: An application of the psychological and behavioral approaches. Journal of Small Business and Enterprise Development, 19(3), 424-440.

Fitzsimmons, J. R., \& Douglas, E. J. (2011). Interaction between feasibility and desirability in the formation of entrepreneurial intentions. Journal of Business Venturing, 26(4), 431-440.

Gupta, V. K., Turban, D. B., Wasti, S. A., \& Sikdar, A. (2009). The role of gender stereotypes in perceptions of entrepreneurs and intentions to become an entrepreneur. Entrepreneurship: Theory and Practice, 33(2), 397-417.

Hair, F., Jr., Babin, B. J., Money, A., \& Samouel, P. (2005). Fundamentos de métodos de pesquisa em administração. Porto Alegre: Bookman.

Hair, F., Jr., Black, W. C., Babin, B. J., Anderson, R. E., \& Tatham, R. L. (2009). Análise multivariada de dados. Porto Alegre: Bookman. 
Honig, B. (2001). Learning strategies and resources for entrepreneurs and intrapreneurs. Entrepreneurship: Theory and Practice, 26(1), 21-36.

Jöreskog, K. G., \& Goldberger, A. S. (1975). Estimation of a model with multiple indicators and multiple causes of a single latent variable. Journal of the American Statistical Association, 70(351 a), 631-639.

Krueger, N. F., \& Brazeal, D. V. (1994). Entrepreneurial potential and potential entrepreneurs. Entrepreneurship: Theory and Practice, 18, 91.

Krueger, N. F., \& Carsrud, A. L. (1993). Entrepreneurial intentions: Applying the theory of planned behaviour. Entrepreneurship \& Regional Development, 5(4), 315-330.

Krueger, N. F. (1993). The impact of prior entrepreneurial exposure on perceptions of new venture feasibility and desirability. Entrepreneurship: Theory and Practice, 18(1), 5-22.

Liñán, F., \& Chen, Y. W. (2009). Development and Cross-Cultural application of a specific instrument to measure entrepreneurial intentions. Entrepreneurship: Theory and Practice, 33(3), 593-617.

Lumpkin, G. T., \& Dess, G. G. (1996). Clarifying the entrepreneurial orientation construct and linking it to performance. Academy of management Review, 21 (1), 135-172.

Monsen, E., Patzelt, H., \& Saxton, T. (2010). Beyond Simple Utility: Incentive Design and Trade-Offs for Corporate Employee-Entrepreneurs. Entrepreneurship: Theory and Practice, 34 (1), 105-130.

Morris, M. H., \& Kuratko, D. F. (2002). Corporate entrepreneurship: Entrepreneurial development within organizations. Nashville, USA: Southwestern Publishing Group.

Parker, S. C. (201 1). Intrapreneurship or entrepreneurship? Journal of Business Venturing, 26(1), 19-34.

Pinchot III, G. (1985). Intrapreneuring: Why you don't have to leave the corporation to become an entrepreneur. New York: Harper and Row.

Thompson, E. R. (2009). Individual entrepreneurial intent: Construct clarification and development of an internationally reliable metric. Entrepreneurship: Theory and Practice, 33(3), 669-694.

Urban, B. (2013). Influence of the institutional environment on entrepreneurial intentions in an emerging economy. The International Journal of Entrepreneurship and Innovation, 14(3), 179-191. 


\section{Como citar este artigo:}

ABNT

MARCHIORI, Danilo Magno; MADEIRA, Maria José Aguilar; DINIS, Anabela do Rosario Leitão. Antecedents of entrepreneurial and intrapreneurial intentions: Evidence from Brazil. RACE, Revista de Administração, Contabilidade e Economia, Joaçaba: Ed. Unoesc, v. 17, n. 3, p. 913-926, set./dez. 2018. Disponível em: <http://editora.unoesc.edu.br/index.php/race>. Acesso em: dia/mês/ano.

APA

Marchiori, D. M., Madeira, M. J. A., \& Dinis, A. do R. L. (2018). Antecedents of entrepreneurial and intrapreneurial intentions: Evidence from Brazil. RACE, Revista de Administração, Contabilidade e Economia, 17(3), 913-926. Retirado de http://editora.unoesc.edu.br/index.php/race 